\title{
INTENTION TO ADOPT E-LEARNING: FAMILIARITY AND INFORMATION QUALITY
}

\author{
Amal Ahmed Ali Qahur \\ College of Commerce and Business Adminstration, \\ Dhofar University.
}

\begin{abstract}
This paper sought to assess the Influence of Familiarity and Information Quality on Intention to Adopt E-Learning. The researcher utilized a quantitative methodology based on survey questionnaire. Primary data was collected using online questionnaire, only 123 responses were valid for analysis. The measurement items for the variables were adopted from validated instruments and published articles and books used as a secondary source for getting data for this study. An appropriate statistical analysis tests were used to check the instrument reliability (Cronbach's alpha) and testing research hypotheses (multiple linear regression test). To get this statistical test done the SPSS software was used. The findings show that Familiarity has a positive effect on the students to adopt E-Learning, whereas, Information Quality does not affect the intention to adopt e-learning. It is necessary that Universities should encourage students to adopt the electronic learning, e-learning system should be qualified and easy for use by students.
\end{abstract}

Keywords - Familiarity, Information Quality, Intention to Adopt E-Learning.

\section{INTRODUCTION}

The increasing demand for higher education and the widespread of communications and information technology are ones of the important variables affecting the current era [1], whose positive and negative effects have been reflected on society institutions in general and the educational and educational institutions in particular, where it represent realistic examples of educational problems that require unconventional solutions [2].

These changes led to the inability of traditional educational institutions and their staffs in facing these problems, which constituted an increasing pressure on the current educational systems, which led them to adopt new patterns of education, the most prominent of which was electronic education. Despite the growing growth of elearning, there are many challenges facing its implementation, as they mentioned that adopting e-learning in university education requires providing an electronic learning environment that has its human requirements, and this is represented in forming a diverse team of experiences who cooperate with each other in performing specific and planned functions [3].

The success of e-learning depends on the university's readiness and acceptance of this adoption through a number of components, the most important of which is the readiness of its faculty members, and the extent to which they possess the values, intentions to use, and competencies necessary for this type of education [4]. The higher the level of this components adoption, the higher their level of readiness and claim for the success of e-learning.

The faculty, the student, and the quality of education are among the most important and influential pillars of the university education system [5]. This research work will seek to determine the Influence of Familiarity and Information Quality on Intention to Adopt E-Learning.

Whatever, electronic learning (e-learning), like other ecommerce application, still not investigated sufficiently. In the context of the study the adoption of technology has been investigated by few research, work process digitalization[6], providing e-government services from citizens as well as employees perspectives [7]-[9], accepting E-Mail System University Students[10], Clients acceptance of Internet Banking[11], adopting ICT by SMEs employees [12], and customers attitudes to adopt e-shopping [13]. Moreover, from the teaching assessment perspective also few studies has been done in the context of the study[14].

Therefore, This research examines the influence few selected factors on adopting e-learning in the educational sector. The study is conducted to check whether the familiarity and information quality have any role in encouraging students to adopt e-learning.

\section{LITERATURE REVIEW}

According to the study of Al-Fraihat et al. (2020), each of Familiarity and Information Quality were studied as factors influencing the intention of the E-learning adoption[15]. This study revealed that both of Familiarity and Information Quality considered as main factors influencing the intention to use of the electronic and virtual learning. Alkhattabi et al. (2019) found that familiarity consists in the learner's knowledge of the concept of electronic learning and knowledge of its technical and scientific requirements[16]. 


\section{International Journal of Engineering Applied Sciences and Technology, 2020 \\ Vol. 5, Issue 3, ISSN No. 2455-2143, Pages 120-123 \\ Published Online July 2020 in IJEAST (http://www.ijeast.com)}

Alkhalaf et al. (2018) defined Information Quality was defined as including the scientific and pedagogical content of the information to be taught or the scientific content in general. But the study of Vululleh, P. (2018) and the study of Rafique et al. (2020) concluded that student's behavioral intention to use e-learning was significantly influenced by the following factors; Quality of life, Perceived ease of use, Perceived usefulness, Social influence[5], [17].

The study of Vululleh, P. (2018) conducted the ETAM model by incorporating 2 motivation attributes; social influence and quality of life in Liberia on 269 students whereas the study of Rafique et al. (2020) conducted the Technology Acceptance Model (TAM) on a sample of 460 undergraduate students (Software Engineering and Bachelor of Computer Science). Both of these studies disclosed that learning intentions greatly impacted by the conducted factors. According to the study of Al-Fraihat, D., Joy, M., \& Sinclair, J. (2020) which aimed to evaluate the E-learning systems success within UK universities. Through the adoption of the PLS-SEM model. This paper studied the following factors influencing the e-learning adoption; Perceived usefulness, Information quality, Technical system quality, Learner quality, Service quality, Instructor quality and the Support system quality. This paper concluded that the above constructs played a key factor in the perceived satisfaction, and adoption of the e-learning for the UK students.

Based on the study of Kisanjara (2020) and the study of Alkhalaf et al. (2013), the common goal was to examine the social attributes, user characteristics, technological characteristics, pedagogical characteristics and environmental characteristics factors affecting electronic learning adoption in Tanzanian universities[18], [19]. It is inferred from the obtained results that these factors positively impacted electronic learning adoption level.. Based on above reviewed literature the following hypotheses are suggested which are represented in figure 1 the suggested research model:

H1: Familiarity has an effect on the intention to adopt e-learning.

$\mathrm{H} 2$ : Information Quality has an effect on the intention to adopt e-learning.

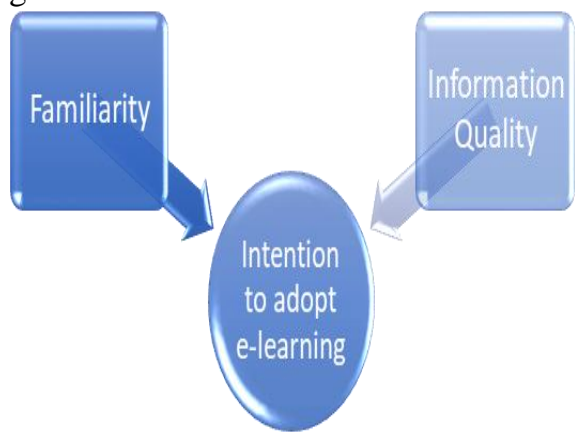

Figure 1: Study Model

\section{RESEARCH METHODS}

This study will be done in the academic frame. The study is aimed to determine the effect of familiarity and information quality on intention to adopt e-learning.

Primary data was collected using online questionaire, only 123 responses were valid for analysis. The measrement items for the variables were adopted from validated instruments[20], [21] and published articles and books used as a secondary source for getting data for this study.

An appropriate statistical analysis tests were used to check the instrument reliability (Cronbach's alpha )[22]-[24] and testing research hypotheses (multiple linear regression test)[25], [26]. To get this statistical test done the SPSS software was used.

\section{ANALYSIS}

Table 1 reliability test

\begin{tabular}{lc}
\hline Variable & Cronbach's Alpha \\
\hline Familiarity & 0.643 \\
Information Quality & 0.828 \\
e-learning adoption & 0.730 \\
\hline
\end{tabular}

Multiple regression analusis used for hypotheses testing. Its results presented in the following tables $(2,3,4)$

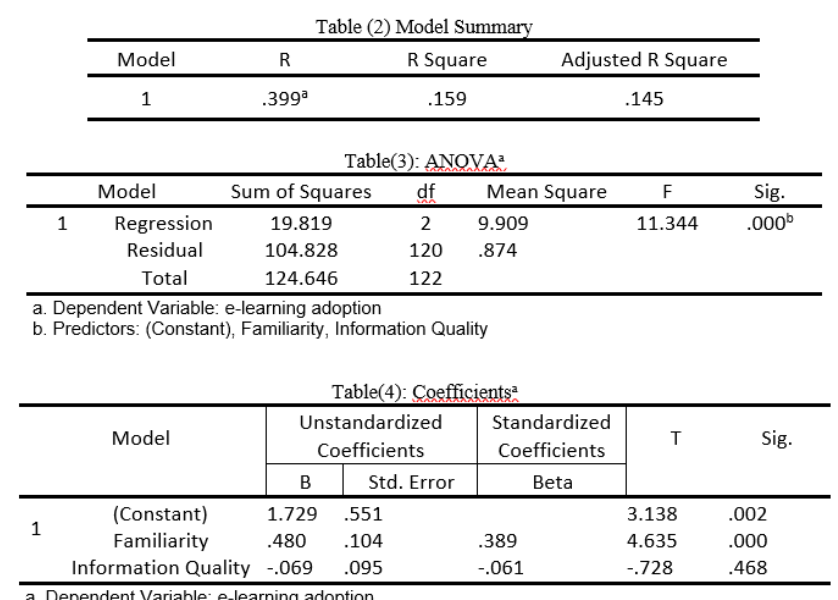

Familiarity and information quality has been checked to find out whether they have an effect on intention to adopt elearning as shown in table $(2)(\mathrm{R} 2=0.159)$ have explained $(15.9 \%)$ of the variance in intention to adopt e-learning. Table (3) shows $F$ test $(F=3.11)$ is significant at $(P<0.05)$. The results of regression analysis shows that familiarity has a positive effect $(\beta=0.389$, sig. $=0.00)$ on Intention to adopt elearning see table (4). Whereas, information quality does not 


\section{International Journal of Engineering Applied Sciences and Technology, 2020 \\ Vol. 5, Issue 3, ISSN No. 2455-2143, Pages 120-123 \\ Published Online July 2020 in IJEAST (http://www.ijeast.com)}

affect $(\beta=-0.061$, sig. $=0.468)$ the intention to adopt $\mathrm{e}$ learning.

\section{DISCUSSION}

The study found the Familiarity has a significant effect on the Intention to adopt e-learning. This result is in agree with results of (Alkhattabi et al., 2019) which explain that students in Dhofar University are familiar in the use of the e-learning system,

The study found the Information Quality has not an effect on the Intention to adopt e-learning. This result is in disagree with results of (Al-Fraihat et al., 2019) which explain that e-learning system in Dhofar University is not qualified and need to overall review.

It is necessary that Universities should encourage students to adopt the electronic learning, e-learning system should be qualified and easy for use by students.

This quantitative study sought to evaluate the Influence of Familiarity and Information Quality on Intention to Adopt ELearning University students. The data gathered via the questionnaire and analyzed with the help of the SPSS program. This research concluded that both familiarity and partially information quality played a significant role on the intention to adopt E-learning.

\section{REFERENCE}

[1] M. Salam, D. N. Awang Iskandar, D. H. A. Ibrahim, and M. S. Farooq, "Technology integration in servicelearning pedagogy: A holistic framework," Telemat. Informatics, vol. 38, pp. 257-273, May 2019, doi: 10.1016/j.tele.2019.02.002.

[2] J. Luo, R. Boland, and C. H. Chan, "How to Use Technology in Educational Innovation," in Roberts Academic Medicine Handbook, Springer International Publishing, 2020, pp. 141-147.

[3] A. Moubayed, M. Injadat, A. Shami, and H. Lutfiyya, "Student Engagement Level in an e-Learning Environment: Clustering Using K-means," Am. J. Distance Educ., vol. 34, no. 2, pp. 137-156, Apr. 2020, doi: 10.1080/08923647.2020.1696140.

[4] S. Norollahee, R. Hakimzadeh, F. Seraji, and M. N. Zare, "ourses in Hadith Science Virtual Faculty According to the Criteria of Quality in E-Learning from the Views of Students and Instructors," Interdiscip. J. Virtual Learn. Med. Sci., vol. 4, no. 2, pp. 1-12, Jan. 2020, Accessed: 31-Jul-2020. [Online]. Available: http://mediaj.sums.ac.ir/online.

[5] P. Vululleh, "Determinants of students' e-learning acceptance in developing countries: An approach based on Structural Equation Modeling (SEM)," 2018.

[6] M. N. Alraja, M. A. Hussein, and H. M. S. Ahmed, "What affects digitalization process in developing economies? an evidence from SMEs sector in Oman," Bull. Electr. Eng. Informatics, vol. 10, no. 1, Feb. 2021, doi: 10.11591/EEI.V10I1.2033.

[7] M. N. Alraja, S. Hammami, and T. Alhousary,
"Factors affecting e-government services adoption: Field study," J. Theor. Appl. Inf. Technol., vol. 78, no. $1,2015$.

[8] M. N. Alraja, S. Hammami, B. Chikhi, and S. Fekir, "The influence of effort and performance expectancy on employees to adopt E-government: Evidence from Oman," Int. Rev. Manag. Mark., vol. 6, no. 4, 2016.

[9] M. N. Alraja, "The effect of social influence and facilitating conditions on e-government acceptance from the individual employees' perspective | Efekt Wpływu Społecznego Oraz Warunków Ułatwiających Akceptację E-Administracji Z Punktu Widzenia Indywidualnych Pracowników," Polish J. Manag. Stud., vol. 14, no. 2, 2016, doi: 10.17512/pjms.2016.14.2.02.

[10] M. N. Alraja, "User Acceptance of Information Technology: A Field Study of an E-Mail System Adoption from the Individual Students' Perspective," Mediterr. J. Soc. Sci., vol. 6, no. 6 s1, pp. 19-25, Nov. 2015, doi: 10.5901/mjss.2015.v6n6s1p19.

[11] M. N. Alraja, B. F. Salim, M. A. Uddin, and M. Yousoof, "The adoption of internet banking: Clients' perspective in Oman," Int. Rev. Manag. Mark., vol. 6, no. 4, 2016.

[12] M. A. Hussein, H. Ahmed, and M. N. Alraja, "The adoption of information and communication technology by small and medium enterprises in Oman: Case of Dhofar region," J. Bus. Retail Manag. Res. www.jbrmr.com A J. Acad. Bus. Retail Manag., vol. 11, no. 3, pp. 64-71, 2017, Accessed: 02-May-2017. [Online]. Available: http://www.jbrmr.com/admin/content/pdf/content_650 13_17-04-22-11-45-45.pdf.

[13] M. N. Alraja and B. Chikhi, "Perceived Factors affecting Customers Attitudes toward Electronic Shopping: an Empirical Study," Int. J. Econ. Res., vol. 12, no. 3, pp. 815-823, 2015, Accessed: 17-May2019. [Online]. Available: http://serialsjournals.com/abstract/51627_17.pdf.

[14] M. A. Uddin, F. Ahmar, and M. N. Alraja, "Eexaminations for management students in Oman," Int. J. Appl. Bus. Econ. Res., vol. 14, no. 1, 2016.

[15] D. Al-Fraihat, M. Joy, R. Masa'deh, and J. Sinclair, "Evaluating E-learning systems success: An empirical study," Comput. Human Behav., vol. 102, pp. 67-86, Jan. 2020, doi: 10.1016/j.chb.2019.08.004.

[16] M. Alkhattabi, D. Neagu, and A. Cullen, "Information Quality Framework for e-Learning Systems," Knowl. Manag. E-Learning An Int. J., vol. 2, no. 4, pp. 340362, 2019, Accessed: 31-Jul-2020. [Online]. Available: http://www.malkhattabi.com.

[17] W. Rafique, W. Dou, K. Hussain, and K. Ahmed, "Factors influencing programming expertise in a webbased e-learning paradigm," Online Learn. J., vol. 24, no. 1, pp. 162-181, 2020, doi: 
10.24059/olj.v24i1.1956.

[18] S. Kisanjara, "FACTORS INFLUENCING ELEARNING IMPLEMENTATION IN TANZANIAN UNIVERSITIES," Online J. Distance Educ. eLearning, vol. 8, no. 1, pp. 37-54, 2020, Accessed: 31-Jul-2020. [Online]. Available: www.tojdel.net.

[19] S. Alkhalaf, A. T. A. Nguyen, S. Drew, and V. Jones, "Measuring the information quality of e-learning systems in KSA: Attitudes and perceptions of learners," in Advances in Intelligent Systems and Computing, 2013, vol. 208 AISC, pp. 787-791, doi: 10.1007/978-3-642-37374-9_75.

[20] M. N. Alraja, S. F. Khan, B. Khashab, and R. Aldaas, "Does Facebook Commerce Enhance SMEs Performance? A Structural Equation Analysis of Omani SMEs," SAGE Open, vol. 10, no. 1, p. 215824401990018, Jan. 2020, doi: $10.1177 / 2158244019900186$.

[21] M. N. Alraja and M. A. Kashoob, "Transformation to electronic purchasing: an empirical investigation," TELKOMNIKA (Telecommunication Comput. Electron. Control., vol. 17, no. 3, pp. 1209-1219, Jun. 2019, doi: 10.12928/TELKOMNIKA.V17I3.9390.

[22] M. N. Alraja and N. M. M. Malkawi, "E-Business adoption in banking sector: Empirical study," Indian J. Sci. Technol., vol. 8, no. 27, 2015, doi: 10.17485/ijst/2015/v8i27/70739.

[23] M. N. Alraja and N. R. ALomiam, "THE EFFECT OF GENERAL CONTROLS OF INFORMATION SYSTEM AUDITING IN THE PERFORMANCE OF INFORMATION SYSTEMS :FIELD STUDY," Interdiscip. J. Contemp. Res. Bus., vol. 5, no. 3, pp. 356-370, 2013, Accessed: 03-Aug-2019. [Online]. Available: https://journal-archieves34.webs.com/356370.pdf.

[24] M. N. Alraja, M. M. J. Farooque, and B. Khashab, "The Effect of Security, Privacy, Familiarity and Trust on Users' Attitudes Towards the Use of IoT-based Healthcare: The Mediation Role of RiskPerception," IEEE Access, vol. 7, pp. 1-1, 2019, doi: 10.1109/access.2019.2904006.

[25] M. N. Alraja and N. R. Alomian, "THE EFFECT OF INFORMATION TECHNOLOGY IN EMPOWERMENT PUBLIC SECTOR EMPLOYEES: A FIELD STUDY," Interdiscip. J. Contemp. Res. Bus., vol. 5, no. 1, pp. 805-815, 2013, Accessed: 17-May-2019. [Online]. Available: https://journal-archieves32.webs.com/805-815.pdf.

[26] N. M. M. A. Malkawi, M. N. Alraja, and T. Alkhayer, "Information Systems Auditing Applied Study at Banks Listed in the Damascus Stock Exchange Syria," Eur. J. Econ. Financ. Adm. Sci., no. 21, p. 119, 2010, Accessed: 17-May-2019. [Online]. Available: http://connection.ebscohost.com/c/articles/52428507/i nformation-systems-auditing-applied-study-banks- listed-damascus-stock-exchange-syria. 